\title{
The role of corporate social responsibility in online identity construction: An analysis of Turkey's banking sector
}

\author{
Sirin Atakan-Duman ${ }^{\mathrm{a}, *}$, Emel Ozdora-Aksak ${ }^{\mathrm{b}}$ \\ a Turgut Ozal University, Faculty of Economics and Administrative Sciences, Department of Business Administration, Turkey \\ b Bilkent University, Faculty of Fine Arts, Design and Architecture, Department of Communication and Design, Turkey
}

\section{A R T I C L E I N F O}

\section{Article history:}

Received 24 November 2013

Received in revised form 8 July 2014

Accepted 21 July 2014

\section{Keywords:}

Corporate social responsibility

Public relations

Institutional theory

Organizational identity

Turkey's banking sector

\begin{abstract}
A B S T R A C T
This study focuses on Turkey's banking sector and investigates the role of public relations and corporate social responsibility practices in constructing organizational identities through a thematic content analysis of banks' corporate websites. Based on social identity theory, the research reveals that regardless of its core business function, an organization must communicate non-economic social concerns to construct a public identity and gain legitimacy.
\end{abstract}

(c) 2014 Elsevier Inc. All rights reserved.

\section{Introduction}

This study aims to determine how organizations define themselves and communicate their distinctive characteristics to create a positive identity through their websites. This research also focuses on understanding the influence of corporate social responsibility (CSR) activities on organizational identity construction. The researchers investigated the public relations and CSR efforts of Turkey's largest public and private banks (with 'largest' identified as banks with more than 300 branches); eight banks met this criterion. Based on institutional theory, this study establishes a linkage between organizational identity and CSR, which has not been explored in detail in the literature. In addition, the study presents CSR data from Turkey's banking sector, a topic which has not been addressed thoroughly.

\section{Theoretical framework}

Apart from building and nurturing mutually beneficial relationships between an organization and its publics (Bruning \& Ledingham, 2000; Ledingham, 2006; Ki \& Hon, 2007), public relations is also instrumental in projecting a desirable organizational identity to external stakeholders (Bromley, 1993; Dowling, 1994; Dutton \& Dukerich, 1991; Van Riel, 1995). Social identity theory, rooted in Tajfel, 1974 early studies, defines organizational identity as 'what the organization is (Balmer, 1995; Hatch \& Schultz 2002; Van Rekom 1997; Van Riel, 1995). When organizations construct their identities, they adapt to their environments through isomorphism mechanisms and conform to environmental norms to increase their chances of survival and success. Therefore, organizations should adapt to the rules and requirements of the environment not only for efficiency reasons, but also to increase their ability to attain resources and gain legitimacy (Kondra \& Hinings, 1998).

\footnotetext{
* Corresponding author. Tel.: +90 5322449459.

E-mail addresses: sduman@turgutozal.edu.tr, sirinatakan@yahoo.com (S. Atakan-Duman), emel.ozdora@bilkent.edu.tr (E. Ozdora-Aksak).
} 
Gaining legitimacy has also become critical for companies' survival and success. Corporate social responsibility is now part of companies' non-economic agendas, with moral, ethical, and social implications that promote mutually beneficial relationships between an organization and its existing and potential publics. Communicating CSR initiatives should focus on establishing a linkage between an organization's identity and its CSR practices. The authors argue that because the Internet is increasingly becoming an indispensable public relations tool, this medium is also an important tool for CSR communication.

In fact, the Internet creates many opportunities for Turkey's population. Turkey has the fifth-most engaged Internet audience in the world (Comscore, 2011). As of June 2012, 45.7\% of the Turkish population can access the Internet, which equals approximately 36.5 million people, making Turkey the 15th-biggest global Internet user (Internet World Stats, 2012). Public relations efforts in Turkey are also been increasingly going online. Alikilic and Atabek (2012) examine PR professionals' Internet use in Turkey and find that they see online communication as a new opportunity for practicing public relations.

\section{Methodology}

This study aims to understand the role of public relations and CSR as a factor in corporate identity construction. The language used on the websites of Turkey's eight largest banks to communicate their organizational identities is the main focus of the study. However, to execute the conceptual analysis with a manageable amount of data, the study does not include foreign-owned banks established in Turkey, foreign-owned banks with branches in Turkey, privately owned commercial and investment banks, Islamic banks, or development banks. The study does include state-owned mutual savings banks (Ziraat Bank, Halk Bank, and Vakıf Bank) and privately owned mutual savings banks (Akbank, Turk Ekonomi Bank, Garanti Bank, İş Bank, and Yapı Kredi Bank) (TBB, 2013).

The researchers extracted the textual data for this study from the About us, History, Mission and Vision, and Corporate Social Responsibility sections on the official websites of each bank in July 2013. Through pre-readings and detailed readings, content analysis was executed on the textual data to attain a deeper understanding of it and help determine the main topics. Text blocks that focused on certain issues were identified and coded as themes. These themes were then categorized under comprehensive headings, which allowed the researchers to develop theme categories. The researchers next compared the themes and theme categories to determine the unique positioning of each bank, which qualities it emphasizes, and its relative emphasis on CSR.

\section{Findings}

The results of the study's in-depth conceptual analysis reveal that each bank utilizes a different set of themes to identify itself and that it continuously communicates its identity through those distinctive word groups. The themes utilized by each bank were grouped into two content categories: general and corporate social responsibility. The general content category only includes text from homepages, About Us sections and other related general content pages of the banks' websites. The corporate social responsibility content only covers text published under that heading.

The researchers believe that the theme categories themselves can be grouped into two main areas: economic outputs and non-economic outputs. Economic outputs include the theme categories of superiority (e.g. strong, leader, first) and core banking functions (e.g. productivity, profitability, customer orientation), while non-economic outputs include extensive impact and development (e.g. sustainability, growth, partnership), future orientation (e.g. change, innovation), and being ethical (e.g. CSR, fairness, openness). The results show that almost all eight banks concentrate on extensive impact and development and core banking functions; three emphasize superiority and another three emphasize being ethical. The remaining two banks did not have a distinct identity emphasis.

\section{CSR as a distinct identity factor}

The two most common themes emphasized by almost all the banks were corporate social responsibility and sustainability. These results are striking because they mean that banks do not construct their identities based on core banking functions, i.e. economic outputs, but instead on extensive impact and development and being ethical, which are non-economic outputs. More specifically, all banks studied utilize CSR as a distinctive identity factor, except for Turk Economi. Similarly, sustainability is utilized by all banks except Turk Economi and Halk. The most commonly emphasized economic output is customer orientation, which is emphasized by all banks except for Yapı Kredi and İs. These findings indicate that Turkey's eight largest banks prefer to highlight non-economic outputs when communicating their identities to their stakeholders. Among these non-economic outputs, CSR plays an important role in identity construction.

\section{Analysis and conclusion}

As institutional theory suggests, compliance within the environment is vital for organizational survival and competitiveness. This pressure to conform is rooted not only in efficiency concerns, but also in the need to gain legitimacy (Kondra \& Hinnings, 1998). Although banks exist on their core banking functions, which are solely economic, they strive to construct their identities on non-economic concerns so as to be perceived as trustworthy corporate citizens that exist for society's 
benefit, rather than being perceived as revenue-maximizing entities for their shareholders. This research reveals that regardless of its core business function, an organization must communicate non-economic social concerns to construct a positive identity as well as to gain and sustain legitimacy.

As Fombrun and Shanley (1990) argue, the public cares about organizations' non-economic agendas. In fact, communicating such agendas, especially CSR-related activities, has become a critical public relations instrument for gaining legitimacy and a competitive advantage. Organizations increasingly integrate CSR into their public relations agendas and emphasize it as the core focus of their communication efforts.

Utilizing institutional theory, this study contributes to the literature by revealing the significance of CSR for organizations' public relations efforts and identity construction. The scope of this research allowed the authors to identify the variety of themes banks use to construct and communicate their identities. These findings provide a general understanding of the topic, but do not allow for investigating the different themes in detail. Concentrating on a specific theme and conducting a quantitative analysis with a larger sample will likely enable making generalizations and developing a deeper understanding of how CSR relates to public relations and identity construction. This study focused only on Turkish banks; the analysis could be broadened to a cross-cultural examination to determine whether CSR practices transcend cultural boundaries.

\section{Acknowledgment}

This work has been funded by The Scientific and Technological Research Council of Turkey (TUBITAK), grant no. 114 K096.

\section{References}

Alikilic, O., \& Atabek, U. (2012). Social media adoption among Turkish public relations professionals: A survey of practitioners. Public Relations Review, 38, 56-63.

Balmer, J. M. T. (1995). Corporate branding and connoisseurship. Journal of General Management, 21(1), 22-46.

Bromley, D. B. (1993). Reputation. In image and impression management. New York: Wiley.

Bruning, S. D., \& Ledingham, J. A. (2000). Perceptions of relationships and evaluations of satisfaction: An exploration of interaction. Public Relations Review, 26, 85-95.

Comscore. (2011). Turkey in the global Internet and the future of online measurement. Presentation retrieved from http://www.comscore.com/Insights/ Presentations_and_Whitepapers/2011/Turkey_in_the_Global_Internet_and_The_Future_of_Online_Measurement

Dowling, G. R. (1994). Corporate reputations: Strategies for developing the corporate brand. London: Kogan Page.

Dutton, J. E., \& Dukerich, J. M. (1991). Keeping an eye on the mirror: Image and identity in organizational adaptation. Academy of Management Journal, 34, $519-554$.

Fombrun, C., \& Shanley, M. (1990). What's in a Name? Reputation Building and Corporate Strategy. Academy of Management Journal, $33(2), 233-258$.

Hatch, M. J., \& Schultz, M. (2002). The dynamics of organizational identity. Human Relations, 55(8), 989-1018.

Internet World Stats. (2012). Top 20 countries with highest number of Internet users - June 30, 2012. Retrieved from http://www.internetworldstats.com/ top20.htm

Ki, E. J., \& Hon, L. C. (2007). Testing the linkages among the organization-public relationship and attitude and behavioral intentions. Journal of Public Relations Research, 19, 1-23.

Kondra, A. Z., \& Hinnings, C. R. (1998). Organizational Diversity and Change in Institutional Theory. Organization Studies, $19(5), 743-767$.

Ledingham, J. A. (2006). Relationship management: A general theory of public relations. In C. H. Botan, \& V. Hazleton (Eds.), Public relations theory II (pp. 465-483). Mahwah, NJ: Lawrence Erlbaum Associates.

Tajfel, H. (1974). Social identity and intergroup behavior. Social Science Information, 13, 65-93.

The Banks Association of Turkey - TBB. (2013). The Banks Association of Turkey. Retrieved from http://www.tbb.org.tr/modules/banka-bilgileri/banka_sube_ bilgileri.asp?tarih=16.01.2013

Van Rekom, J. (1997). Deriving an operational measure of corporate identity. European Journal of Marketing, 31(5/6), 410-422.

Van Riel, C. B. M. (1995). Principles of corporate communication. London: Prentice Hall. 